\title{
OPEN Prediction of factors affecting activation of soil erosion by mathematical modeling at pedon scale under laboratory conditions
}

\begin{abstract}
Saeed Shojaei ${ }^{1 \bowtie}$, Zahra Kalantari' ${ }^{2,3,4}$ \& Jesús Rodrigo-Comino ${ }^{5,6 \bowtie}$
Soil degradation due to erosion is a significant worldwide problem at different spatial (from pedon to watershed) and temporal scales. All stages and factors in the erosion process must be detected and evaluated to reduce this environmental issue and protect existing fertile soils and natural ecosystems. Laboratory studies using rainfall simulators allow single factors and interactive effects to be investigated under controlled conditions during extreme rainfall events. In this study, three main factors (rainfall intensity, inclination, and rainfall duration) were assessed to obtain empirical data for modeling water erosion during single rainfall events. Each factor was divided into three levels $(-1$, $0,+1)$, which were applied in different combinations using a rainfall simulator on beds $(6 \times 1 \mathrm{~m})$ filled with soil from a study plot located in the arid Sistan region, Iran. The rainfall duration levels tested were 3,5 , and $7 \mathrm{~min}$, the rainfall intensity levels were 30,60 , and $90 \mathrm{~mm} / \mathrm{h}$, and the inclination levels were 5,15 , and $25 \%$. The results showed that the highest rainfall intensity tested $(90 \mathrm{~mm} / \mathrm{h})$ for the longest duration $(7 \mathrm{~min})$ caused the highest runoff $\left(62 \mathrm{~mm}^{3} / \mathrm{s}\right)$ and soil loss $\left(1580 \mathrm{~g} / \mathrm{m}^{2} / \mathrm{h}\right)$. Based on the empirical results, a quadratic function was the best mathematical model $\left(R^{2}=0.90\right)$ for predicting runoff (Q) and soil loss. Single-factor analysis revealed that rainfall intensity was more influential for runoff production than changes in time and inclination, while rainfall duration was the most influential single factor for soil loss. Modeling and three-dimensional depictions of the data revealed that sediment production was high and runoff production lower at the beginning of the experiment, but this trend was reversed over time as the soil became saturated. These results indicate that avoiding the initial stage of erosion is critical, so all soil protection measures should be taken to reduce the impact at this stage. The final stages of erosion appeared too complicated to be modeled, because different factors showed differing effects on erosion.
\end{abstract}

The United Nations has formulated 17 overarching sustainable development goals (No Poverty, Zero Hunger, Good Health and Well-Being, Quality Education, Gender Equality, Clean Water and Sanitation, Affordable and Clean Energy, Decent Work and Economic Growth, Industry, Innovation, and Infrastructure, Reduced Inequalities, Sustainable Cities and Communities, Responsible Consumption and Production, Climate Action, Life Below Water, Life on Land, Peace, Justice and Strong Institutions and Partnerships.) for $2030^{1}$. These include an ambition to combat desertification and reduce land degradation due to different processes such as soil erosion ${ }^{2-7}$. Arid and semi-arid areas are among the most vulnerable areas to soil erosion ${ }^{7,8}$. It is well known that soils are an essential part of the global ecosystem and vital for the survival of human life ${ }^{9-12}$. Humans and natural organisms

\footnotetext{
${ }^{1}$ Department of Management of Arid and Desert Regions, College of Natural Resources and Desert, Yazd University, Yazd, Iran. 'Department of Physical Geography and Bolin Center for Climate Research, Stockholm University, 10691 Stockholm, Sweden. ${ }^{3}$ Navarino Environmental Observatory, 24001 Messinia, Greece. ${ }^{4}$ Department of Sustainable Development, Environmental Science and Engineering, Sustainability Assessment and Management, KTH Royal Institute of Technology, SE-100 44 Stockholm, Sweden. ${ }^{5}$ Soil Erosion and Degradation Research Group, Department of Geography, University of Valencia, 46010 Valencia, Spain. ${ }^{6}$ Department of Physical Geography, University of Trier, 54296 Trier, Germany.『email: s_shojaei@ut.ac.ir; Rodrigo@uni-trier.de
} 
depend on fertile soils for food production, bio-cycling, plant growth, water, carbon and nutrient storage, material decomposition, etc. ${ }^{13,14}$.

Researchers have accurately identified different forms of soil erosion that can occur under different environmental conditions, due to rain, wind, human, or animal influences ${ }^{15-19}$ or caused by morphological and hydrogeological factors ${ }^{20,21}$. Soil erosion induced by human activities, such as agriculture, could be minimized if correct monitoring and assessment were carried out to develop efficient preventive measures. Natural erosion also depends on uncontrollable factors, but it is not necessary to prevent or mitigate this form of erosion ${ }^{22,23}$. Therefore, understanding the nature of erosion induced by human activities is key to conserving ecosystem services ${ }^{24,25}$.

Studies show that soil erosion by running water mainly depends on land inclination, rainfall intensity, and rainfall duration ${ }^{23,26}$ and, logically, on soil properties and land management ${ }^{27,28}$. Under the impact of raindrops and running water on the surface, soil particles are removed from fertile soil and transported away at a rate which depends on the slope of the land and the amount of runoff ${ }^{23}$. However, it is difficult to predict and determine the point at which this process, which is affected by soil saturation or infiltration, could be minimized or stopped ${ }^{29-32}$.

In research into soil erosion, laboratory and plot-scale rainfall simulation experiments allow the different stages of the water erosion process and the influence of single or combined factors to be investigated under controlled conditions ${ }^{33,34}$. The results of such studies can thus help understand the different spatial-temporal patterns of the main factors involved, knowledge required to develop specific local soil conservation strategies ${ }^{35,36}$. For example, recent studies show that inclination plays an important role in the spread of erosion, including spray, furrow, sheet, or mass erosion ${ }^{37,38}$. Kiani-Harchegani et al..$^{39}$ found higher erosion rates under low rainfall intensity on a slope of $25 \%$ compared with $15 \%$, with this increase being directly related to the hillslope inclination. A laboratory study conducted in Italy demonstrated that with increasing inclination and rainfall intensity $(30,60$, and $120 \mathrm{~mm} / \mathrm{h})$, the bed load decreased and the amount of runoff increased, determining the sediment production boundary ${ }^{40}$. A study examining the effect of hillslope inclination on runoff and sediment production showed that with a more gradual inclination, runoff first decreased and then increased, but the amount of sediment decreased consistently ${ }^{41}$. Studies applying a rainfall intensity of around $47 \mathrm{~mm} / \mathrm{h}$ on different inclinations $(3,6$, and $9 \%)$ found that the amount of soil loss showed an inverse negative relationship with inclination ${ }^{42,43}$. In a study in China, researchers found that the rate at which soil particles separated and produced sediment increased at high rainfall intensities, while transfer of soil particles was smallest at low intensities ${ }^{44}$.

In a study in which soils with particles less than 2 and $4.75 \mathrm{~mm}$ diameter on different inclinations $(0.5,2.5,5$, 10 , and 20\%) were subjected to simulated rainfall at an intensity of about $75-80 \mathrm{~mm}$ for one hour, the amount of sediment was found to be highly dependent on the slope in unstable conditions, but not in stable conditions ${ }^{45}$. A study investigating the effect of three intensities of rainfall $(35,65$, and $95 \mathrm{~mm} / \mathrm{h})$ on agricultural soils cropped with rice found that runoff and sediment were highly affected by the vegetation cover, increasing by around $300 \%$ with bare soils ${ }^{46}$.

Overall, however, there have been few studies in which the effects of all three factors (inclination, rainfall intensity, and rainfall duration) have been studied simultaneously, in order to identify single-factor effects or multiple interactions and detect when control measures must be taken. The main aim of this study was therefore to investigate the effect of these three factors, alone and in combination, on the amount of soil loss and runoff produced. To achieve this goal, the main factors were each divided into three levels $(-1,0,+1)$, which were applied in different combinations using a rainfall simulator on beds $(6 \times 1 \mathrm{~m})$ filled with soil from an experimental plot located in the arid Sistan region, Iran. A mathematical model describing the effects of slope, rainfall intensity, and rainfall duration on soil loss and runoff production was then developed. The starting hypothesis was that a model based on accurate data on inclination, rainfall intensity, and rainfall duration can accurately predict the different stages in erosion, information which could be used to develop effective control measures.

\section{Materials and methods}

Soil sampling and rainfall simulation experiments. Soil samples for the laboratory experiments were collected from the topsoil layer $(0-30 \mathrm{~cm})$ in an alluvial area on the Sistan plain in south-east Iran $\left(30^{\circ} 51^{\prime} \mathrm{N}\right.$; $\left.61^{\circ} 01^{\prime} \mathrm{E}\right)$, a region with an arid climate. The soil samples were transported to the Zahedan University Laboratory, Iran, where they were dried in open-air conditions for $24 \mathrm{~h}$. Plant debris and pebbles were then removed, and the entire mass of soil was passed through an $8 \mathrm{~mm}$ sieve. A set of test beds, each measuring $6 \mathrm{~m} \times 1 \mathrm{~m}$, was established outdoors (Fig. 1). A drainage layer of mineral pumice was placed in the bottom of each bed, and then $10 \mathrm{~cm}$ of soil were poured on the top and pressed down lightly. The erosion-influencing factors tested (rainfall intensity, inclination, and rainfall duration) at the different levels $(-1,0,+1)$ were applied to these beds, with artificial rainfall using a rainfall simulator, supplying distilled water with $\mathrm{pH} 7$ (Fig. 1). The three levels of rainfall duration tested were 3,5 , and $7 \mathrm{~min}$, the rainfall intensity levels were 30,60 , and $90 \mathrm{~mm} / \mathrm{h}$, and the inclination levels were 5,15 , and $25 \%$. The slope was achieved by setting the base of the bed the desired inclination before adding soil. Before conducting each experiment, non-erosive precipitation of $5 \mathrm{~mm} / \mathrm{h}$ was applied to prepare the test beds and restore the soil to its natural moisture content ${ }^{47}$. The average rainfall amount in the different intensity and duration treatments was $1.5 \mathrm{~mm}$, the speed of application was $6.8 \mathrm{~m} / \mathrm{s}$, and the power was $0.40 \mathrm{~W} /$ $\mathrm{m}^{2}$. The average runoff power was $0.035 \mathrm{~W} / \mathrm{m}^{2}$.

Measurement of runoff and sediment. Sheet flow runoff at the outlet of the beds during the simulated rainfall events was measured at intervals of one minute, with three replicates of 17 runs. Each test included different combinations of the different factor levels (Table 1). The amount of soil loss produced in each test was collected in a single container (Fig. 1). The dry mass of soil in the container was determined by oven-drying at $105^{\circ} \mathrm{C}$ for $24 \mathrm{~h}$. Based on the amount of soil loss produced in each rainfall event $(3,5$, or $7 \mathrm{~min})$ and plot area $\left(1.6 \mathrm{~m}^{2}\right)$, soil loss per minute was calculated for each intensity of precipitation tested. 


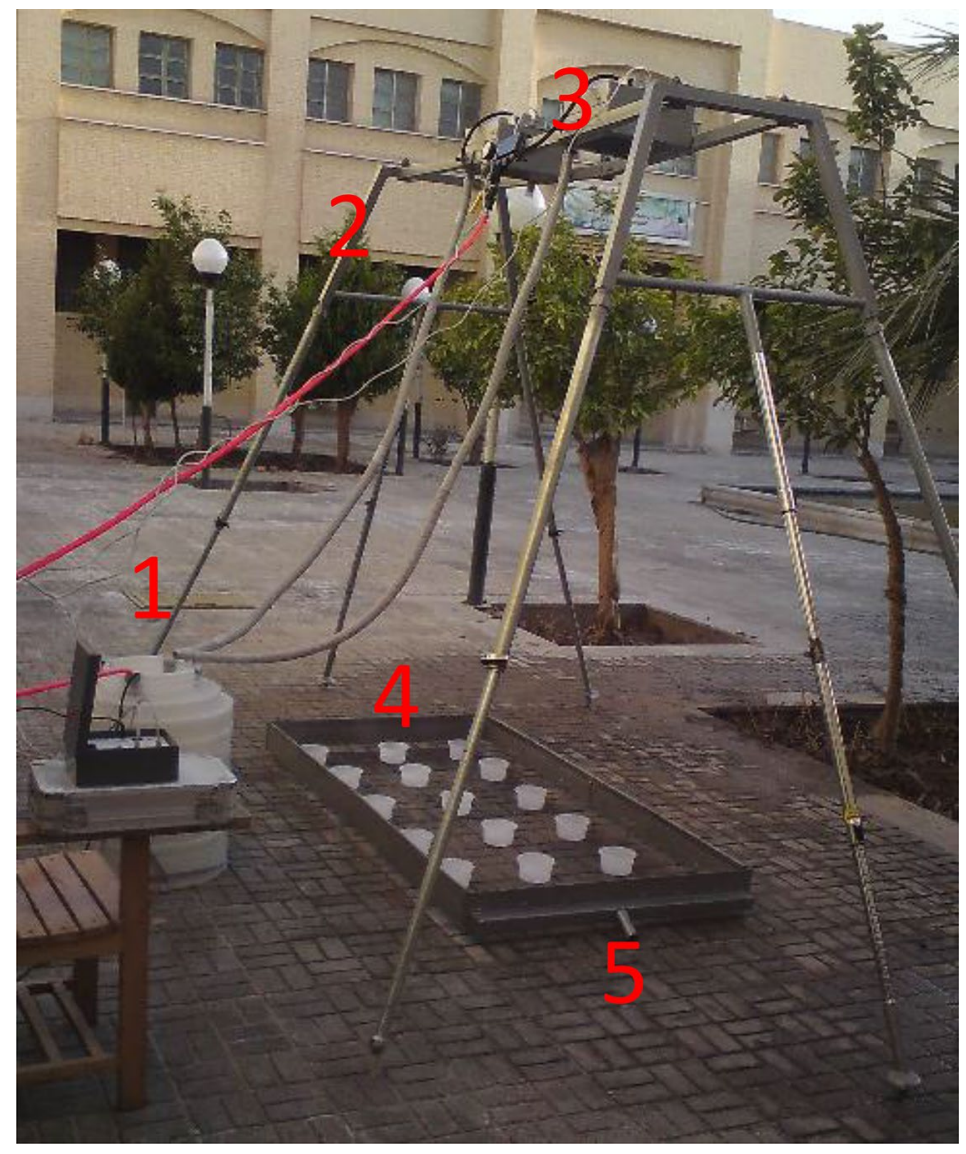

Figure 1. Rainfall simulator used for each test bed. (1) Water tank. (2) Pressure gauge. (3) Micro sprinkler nozzles. (4) Overflow pipe. (5) Measuring cup at the outlet pipe.

\begin{tabular}{|l|l|l|l|l|l|}
\hline \multirow{2}{*}{ Variable } & \multirow{2}{*}{ Units } & Factor code & \multicolumn{3}{|l|}{ Level } \\
\cline { 4 - 7 } & Rainfall intensity & $\mathrm{mm} / \mathrm{h}$ & $\mathrm{A}$ & $\mathbf{0}$ & $\mathbf{1}$ \\
\hline Rainfall duration & $\mathrm{min}$ & $\mathrm{B}$ & 30 & 60 & 90 \\
\hline Inclination & $\%$ & $\mathrm{C}$ & 5 & 5 & 7 \\
\hline
\end{tabular}

Table 1. Different levels tested, units, and codes of the three variables assessed in the laboratory experiment.

Laboratory tests and data treatment. The levels selected for the three rainfall durations (factor A), rainfall intensity levels (factor B), and inclination levels (factor C) in the experiment are shown in Table 1. These levels were chosen based on Eq. (1). Runoff volume and soil loss rate were simulated and predicted using the Design-Expert software 10.0.8 $8^{4-51}$. This software is able to assess the necessary inputs and outputs of a theoretical process in a specific procedure to obtain the most accurate results, in order to identify the optimal process or product. This procedure is useful to reduce time costs and expenses.

$$
x_{i}=\frac{x_{i-} x_{0}}{\Delta x_{i}}
$$

$\mathrm{X}_{\mathrm{i}}=$ Independent encoded variable value, $\mathrm{X}_{0}=$ Center point of actual values of the variable, $\Delta \mathrm{Xi}=\mathrm{Change}$ in value.

Analysis of variance (ANOVA) was applied to the runoff and erosion data obtained. Based on the $P$ values (Table 2), the importance of the variables was evaluated and an appropriate mathematical model was developed (Eq. 2). Signal-to-noise ratio was applied to test the accuracy of the mathematical models, with values greater than 4 taken to denote good accuracy ${ }^{52}$. 


\begin{tabular}{|l|l|l|l|r|r|l|l|}
\hline Source & & Sum of squares & Degrees of freedom & Mean square & F-value & Prob $>$ F & Remarks \\
\hline \multirow{2}{*}{ Runoff } & Quadratic & 616.25 & 3 & 205.42 & 12.86 & 0.0031 & \multirow{2}{*}{ Suggested } \\
\cline { 2 - 8 } & Pure Error & 12.80 & 4 & 3.20 & 1.05 & 0.4045 & \\
\hline \multirow{2}{*}{ Sediment } & Quadratic & 1.842 & 3 & $61,400.00$ & 12.90 & 0.0031 & \multirow{2}{*}{ Suggested } \\
\cline { 2 - 8 } & Pure Error & 0.000 & 4 & 0.000 & 5.74 & 0.0100 & \\
\hline
\end{tabular}

Table 2. Statistical parameters obtained for the model.

\begin{tabular}{|c|c|c|c|c|c|c|}
\hline Source & Sum of squares & DF & Mean square & F-value & $P$ value & Remarks \\
\hline \multicolumn{7}{|l|}{ Runoff } \\
\hline Model & 9806.71 & 9 & 1089.63 & 12.13 & 0.0017 & \multirow{11}{*}{ Significan } \\
\hline Rainfall intensity & 1653.12 & 1 & 1653.12 & 18.40 & 0.0036 & \\
\hline Rainfall duration & 66.12 & 1 & 66.12 & 0.74 & 0.4194 & \\
\hline Inclination & 312.50 & 1 & 312.50 & 3.48 & 0.1045 & \\
\hline $\mathrm{AB}$ & 900.00 & 1 & 900.00 & 10.02 & 0.0158 & \\
\hline $\mathrm{AC}$ & 756.25 & 1 & 756.25 & 8.42 & 0.0230 & \\
\hline $\mathrm{BC}$ & 2652.25 & 1 & 2652.25 & 29.51 & 0.0010 & \\
\hline $\mathrm{A}^{\wedge} 2$ & 2019.41 & 1 & 2019.41 & 22.47 & 0.0021 & \\
\hline $\mathrm{B}^{\wedge} 2$ & 297.09 & 1 & 297.09 & 3.31 & 0.1119 & \\
\hline $\mathrm{C}^{\wedge} 2$ & 843.04 & 1 & 843.04 & 9.38 & 0.0182 & \\
\hline Residual & 629.05 & 7 & 89.86 & & & \\
\hline Lack of Fit & 616.25 & 3 & 205.42 & 64.19 & 0.0008 & Significant \\
\hline \multicolumn{7}{|l|}{ Sediment loss } \\
\hline Model & 2.745 & 9 & 3.050 & 11.59 & 0.0020 & \multirow{12}{*}{ Significant } \\
\hline Rainfall intensity & $12,800.00$ & 1 & $12,800.00$ & 0.49 & 0.5080 & \\
\hline Rainfall duration & 1.656 & 1 & 1.656 & 62.94 & $<0.0001$ & \\
\hline Inclination & 0.000 & 1 & 0.000 & 0.000 & 1.0000 & \\
\hline $\mathrm{AB}$ & $57,600.00$ & 1 & $57,600.00$ & 2.19 & 0.1825 & \\
\hline AC & 0.000 & 1 & 0.000 & 0.000 & 1.0000 & \\
\hline $\mathrm{BC}$ & 0.000 & 1 & 0.000 & 0.000 & 1.0000 & \\
\hline $\mathrm{A}^{\wedge} 2$ & $88,526.32$ & 1 & $88,526.32$ & 3.36 & 0.1093 & \\
\hline $\mathrm{B} \wedge 2$ & 8.717 & 1 & 8.717 & 33.13 & 0.0007 & \\
\hline $\mathrm{C} \wedge^{\wedge} 2$ & 8526.32 & 1 & 8526.32 & 0.32 & 0.5870 & \\
\hline Residual & 1.842 & 7 & $26,314.29$ & & & \\
\hline Lack of Fit & 1.842 & 3 & $61,400.00$ & & & \\
\hline
\end{tabular}

Table 3. Analysis of variance (ANOVA) results obtained for runoff (Q, $\mathrm{mm}^{3} / \mathrm{s}$ ) and erosion (soil loss, $\mathrm{g} / \mathrm{m}^{2} / \mathrm{h}$ ). Runoff $R^{2}=0.9397$, Adj- $R^{2}=0.8622$, signal to noise ratio $=10.591$. Sediment loss $R^{2}=0.9371, \mathrm{Adj}-R^{2}=0.8563$, signal to noise ratio $=9.766$.

$$
Y=b_{0}+\sum_{i=1}^{4} b_{i} x_{i}+\sum_{i=1}^{4} b_{i i} x_{i}^{2}+\sum_{i=1}^{3} \sum_{j=i+1}^{4} b_{i j} x_{i} x_{j}
$$

$Y=$ predicted answer, $\beta_{0}=y$-intercept coefficient, $\beta_{\mathrm{i}}=$ linear coefficient of the parameters, $\beta_{\mathrm{ij}}=$ secondary interaction coefficient, $\mathrm{b}_{\mathrm{ij}}=$ second order coefficient, $\mathrm{x}_{\mathrm{i}}, \mathrm{x}_{\mathrm{j}}=$ independent encoded variables.

\section{Results and Discussion}

Soil erosion results (experimental and predicted). Analysis of variance and factor values for the erosion data showed that the calculated F-value value (11.59) was higher than the observed value (Table 3 ). The $\mathrm{R}^{2}$ value was 0.94 and the Adj- $\mathrm{R}^{2}$ was 0.85 , showing good accuracy of the model (Eq. 2) in predicting and describing soil erosion. The signal-to-noise ratio obtained was 9.766 , also confirming good accuracy of the erosion prediction model.

The scatter plots (Fig. 2) for runoff and soil loss showed that the real and predicted data were close to each other, which confirmed the accuracy of the model in predicting the amount of sediment and runoff (Table 4).

The final models obtained for runoff and soil loss production in the simulated rainfall experiments are shown in Eqs. (3) and (4), respectively. 
Design-Expert( Software Snil Inss

Color boints by value of

1580

200

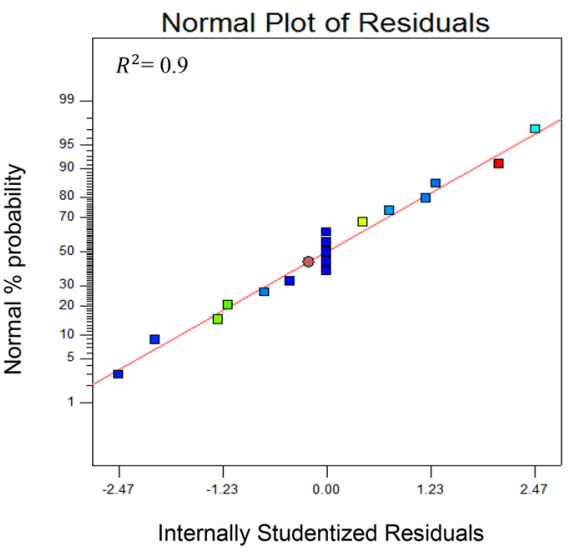

Soil loss
Design-Expert@ Software

Color points by value of

$\prod_{9}^{85}$

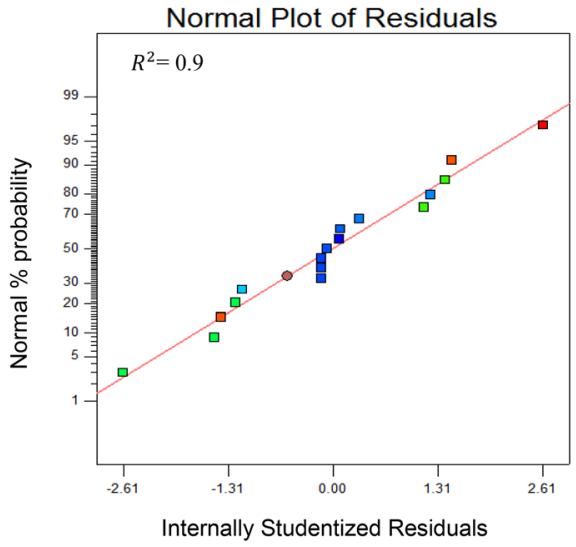

Figure 2. Scatter plot obtained for (left) sediment production and (right) runoff $(\mathrm{Q})$ production. ${ }^{*}$ Corrected to $5 \%$.

\begin{tabular}{|l|l|l|l|l|l|l|l|}
\hline Run & Rainfall & Rainfall & Inclination & Q $\left(\mathrm{mm}^{3} / \mathbf{s}\right)$ & \multicolumn{2}{l|}{ Sediment $\left(\mathrm{g} / \mathbf{m}^{2} / \mathbf{h}\right)$} \\
\hline & intensity & duration & & Experimental & Predicted & Experimental & Predicted \\
\hline 1 & 0 & 0 & 0 & 14 & 15.20 & 200 & 200 \\
\hline 2 & 0 & -1 & 1 & 42 & 54.38 & 210 & 245 \\
\hline 3 & 0 & 1 & 1 & 9 & 8.63 & 1050 & 1155 \\
\hline 4 & 0 & 1 & -1 & 85 & 72.63 & 1190 & 1155 \\
\hline 5 & 0 & 0 & 0 & 16 & 15.20 & 200 & 200 \\
\hline 6 & 1 & -1 & 0 & 79 & 72.00 & 260 & 425 \\
\hline 7 & 0 & 0 & 0 & 18 & 15.20 & 200 & 200 \\
\hline 8 & 0 & 0 & 0 & 14 & 15.20 & 200 & 200 \\
\hline 9 & -1 & 0 & -1 & 24 & 29.38 & 230 & 430 \\
\hline 10 & -1 & 0 & 1 & 51 & 44.38 & 370 & 430 \\
\hline 11 & 0 & -1 & -1 & 15 & 15.38 & 350 & 245 \\
\hline 12 & 0 & 0 & 0 & 14 & 15.20 & 200 & 200 \\
\hline 13 & -1 & -1 & 0 & 19 & 13.25 & 360 & 265 \\
\hline 14 & 1 & 0 & -1 & 79 & 85.63 & 410 & 350 \\
\hline 15 & -1 & 1 & 0 & 42 & 49.00 & 1580 & 1415 \\
\hline 16 & 1 & 1 & 0 & 42 & 47.75 & 1000 & 1095 \\
\hline 17 & 1 & 0 & 1 & 51 & 45.63 & 550 & 350 \\
\hline
\end{tabular}

Table 4. Experimental and predicted results obtained for production of runoff $\left(\mathrm{Q}, \mathrm{mm}^{3} / \mathrm{s}\right.$ ) and erosion (soil loss, $\left.\mathrm{g} / \mathrm{m}^{2} / \mathrm{h}\right)$ in runs $1-17$ of the experiment testing different levels $(-1,0,+1)$ of rainfall intensity, rainfall duration, and inclination (see Table 1 ).

Runoff $=+15.20+14.38 \mathrm{~A}+2.87 \mathrm{~B}-6.25 \mathrm{C}-15.00 \mathrm{AB}-13.75 \mathrm{AC}-25.75 \mathrm{BC}+25.90 \mathrm{~A}^{2}+8.40 \mathrm{~B}^{2}+14.15 \mathrm{C}^{2}$

Soil loss $=+200.0-40.00 \mathrm{~A}+455.00 \mathrm{~B}+0.00 \mathrm{C} 120.00 \mathrm{AB}+0.00 \mathrm{AC}+0.00 \mathrm{BC}+145.00 \mathrm{~A}^{2}+455.00 \mathrm{~B}^{2}+45.00 \mathrm{C}^{2}$

where $A$ is rainfall intensity $(\mathrm{mm} / \mathrm{h}), B$ is rainfall duration ( $\mathrm{min})$, and $C$ is soil loss (\%).

Analysis of variance and factor values obtained from runoff data showed that the calculated F-value (12.32) was higher than the observed value. The $\mathrm{R}^{2}$ value was high $(0.9397)$, showing that the model described the empirical data and predicted erosion with high accuracy. The value of Adj- $\mathrm{R}^{2}$ was also high (0.8622), confirming the accuracy of the model in evaluating the amount of runoff. The signal-to-noise ratio was 10.591, providing further confirmation of model accuracy ${ }^{49}$.

Single-factor analysis of changes in runoff production. The analysis of single-factor effects showed that the amount of runoff was much more strongly affected by changes in runoff intensity than by changes in rainfall duration and inclination (Fig. 3). The amount of runoff increased exponentially with increasing rainfall intensity related to the highest intensity tested $(90 \mathrm{~mm} / \mathrm{h})$. This is because with increasing intensity of rainfall, 

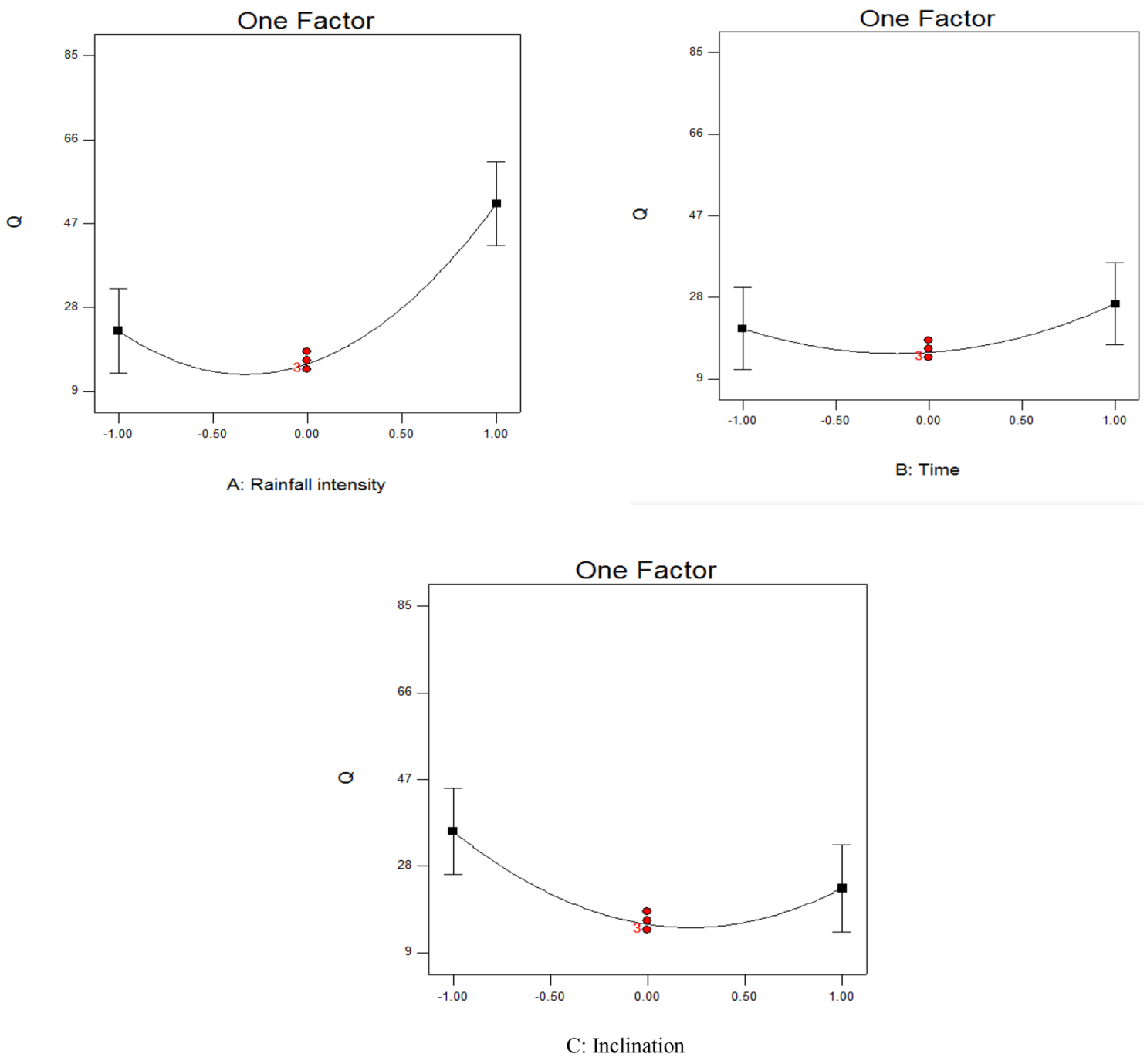

Figure 3. Results of single-factor analysis of the effect of changes in (a) rainfall intensity $(30,60$, and $90 \mathrm{~mm} / \mathrm{h})$, (b) rainfall duration $(3,5$, and $7 \mathrm{~min})$, and $(\mathbf{c})$ inclination $(5,15$, and $25 \%)$ on runoff $\left(\mathrm{Q}, \mathrm{mm}^{3} / \mathrm{s}\right)$ from the test beds.

a greater amount of rainfall reaches the soil surface per unit time and there is less time for it to penetrate the soil, so it runs off the surface. Changes in rainfall duration resulted in few changes in the amount of runoff, with runoff increasing only at the end of the experiment due to the continued rainfall leading to soil saturation.

Runoff volume decreased with an increasing inclination between 5 and 15\%. The reason for this relates to the speed of water flow, i.e., at high slopes runoff is rapidly removed and the thickness of the runoff layer is reduced. Due to the presence of water particles moving at high intensity, the rate of penetration into steeper slopes also increases. When the inclination was increased further to $25 \%$, the amount of runoff began to increase again (Fig. 3). However, a study on a Mollisol in China examining runoff changes due to differences in slope (5 and $10^{\circ}$ ), with rainfall intensity of 0 and $70 \mathrm{~mm} / \mathrm{h}$ (RI0, RI70), found that runoff decreased in the order rainfall intensity $70+$ inflow rate $70>$ rainfall intensity $70+$ inflow rate $0>$ rainfall intensity $0+$ inflow rate 70 , and that increasing the slope from 5 to 10 increased the runoff amount by 2.5 - to 6.9 -fold ${ }^{53}$.

Interactive effects of multiple factors on runoff production. Three-dimensional diagrams were used to represent the simultaneous effect of different factors on the amount of runoff generated by the simulated rainfall experiments (Fig. 4). The diagrams obtained showed that as rainfall intensity increased, the amount of runoff also increased within a shorter time, because of a faster decrease in the amount of water infiltration. An increase in rainfall intensity had the greatest effect in increasing runoff and was most influential in runoff production, giving an exponential increase in runoff production over time (Fig. 4A).

Comparison of the combined effect of inclination and rainfall intensity showed that increasing rainfall intensity produced more runoff than steeper slope. However, with increasing inclination combined with increasing intensity of rainfall, the amount of runoff increased under all conditions (Fig. 4B). Comparison of the combined effect of inclination and rainfall duration showed that both factors had a similar effect in increasing runoff. With increasing time and increasing slope, the amount of runoff increased linearly (Fig. 4C). 


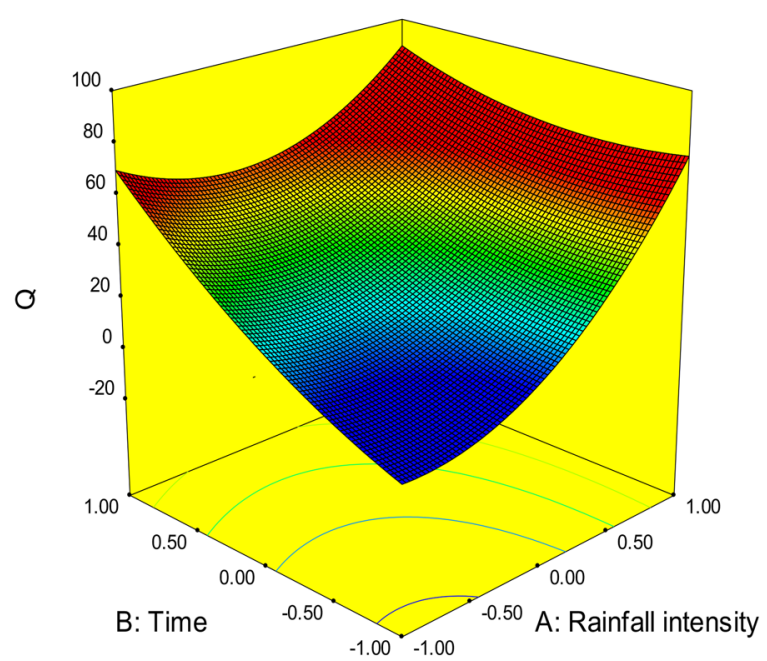

A

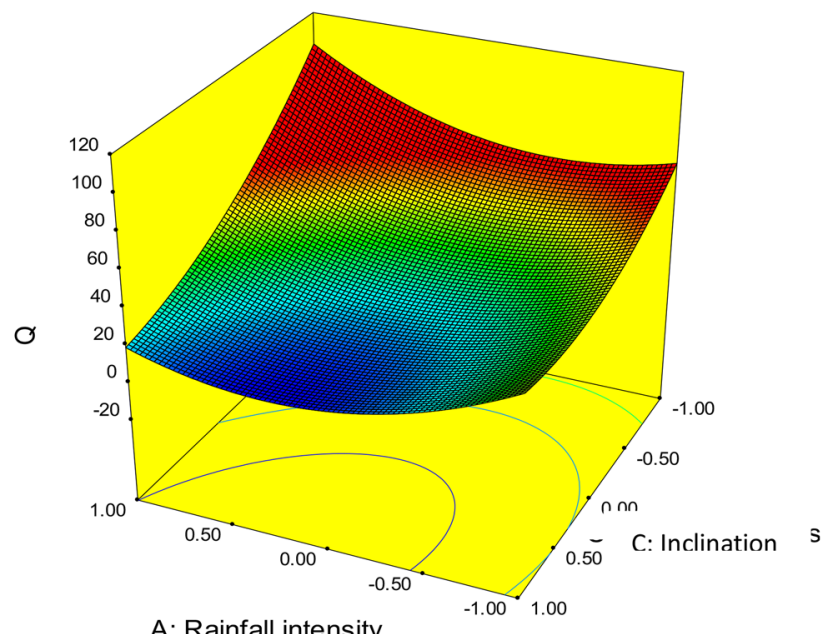

A: Rainfall intensity

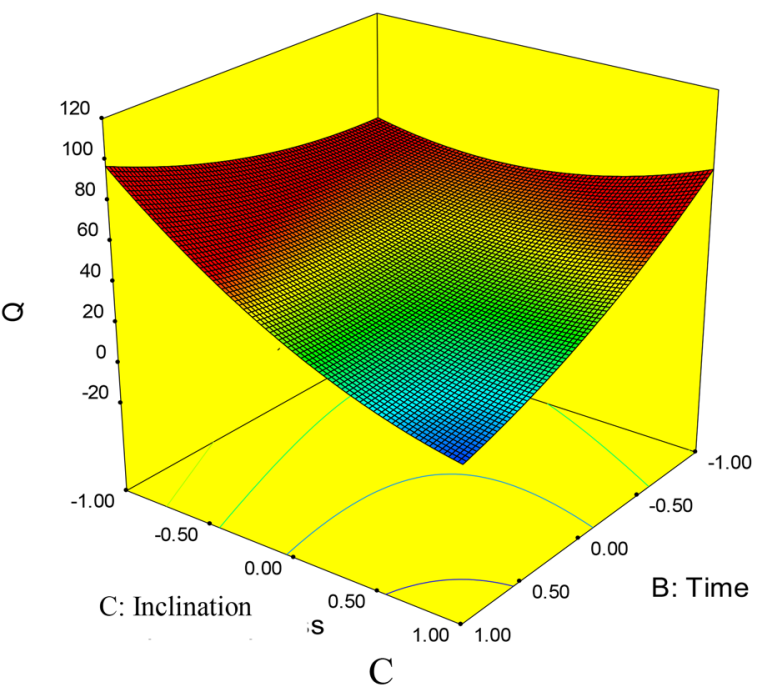

Figure 4. Comparison of the combined effect of (A) rainfall intensity and rainfall duration, (B) rainfall intensity and slope, and $(\mathbf{C})$ rainfall duration and slope on runoff $\left(\mathrm{Q}, \mathrm{mm}^{3} / \mathrm{s}\right)$ from the test beds.

The formation of runoff depends on multiple factors apart from the three main factors examined in this study, such as soil moisture, soil texture and structure, soil surface characteristics, etc. ${ }^{54-56}$. For a given set of soil and site conditions, higher-intensity rainfall can increase runoff and sediment production by more than $30-50 \%$ compared with low-intensity rainfall, and this trend increases with increasing rainfall intensity ${ }^{57}$. For example, a study investigating runoff production from agricultural soils found that increasing the rainfall intensity from 35 to $95 \mathrm{~mm} / \mathrm{h}$ increased runoff production by around threefold, but that soil surface characteristics could be effective in reducing erosion ${ }^{46}$. Production of runoff directly affects the production of sediment, e.g., a change of slope from 5 to $25 \%$ at a rainfall intensity of $90 \mathrm{~mm} / \mathrm{h}$ has been found to increase the amount of runoff by fourfold and the amount of sediment by fivefold ${ }^{39}$.

Single-factor analysis of changes in soil loss. The analysis of single-factor effects showed that the amount of soil loss produced was much more strongly affected by increasing rainfall duration than by changes in rainfall intensity and inclination (Fig. 5). Runoff amount increased exponentially over time, to reach a maximum at a rainfall duration of $7 \mathrm{~min}$, because of a greater volume of sediment entering the sediment trap as rainfall continued. Sediment production was high at the beginning of the experiment, but decreased by the end. Rainfall fluctuations and rainfall intensity directly affect the amount of sediment eroded from soil with a particular texture, while increasing the inclination can increase erosion ${ }^{58,59}$.

In our experiments, increased rainfall intensity first increased, and then decreased, the loss of sediment. This could be because the amount of transportable sediment declined over time, so by the end of each rainfall event there was less to be washed away from the bed surface. With increasing rainfall and increasing diameter 

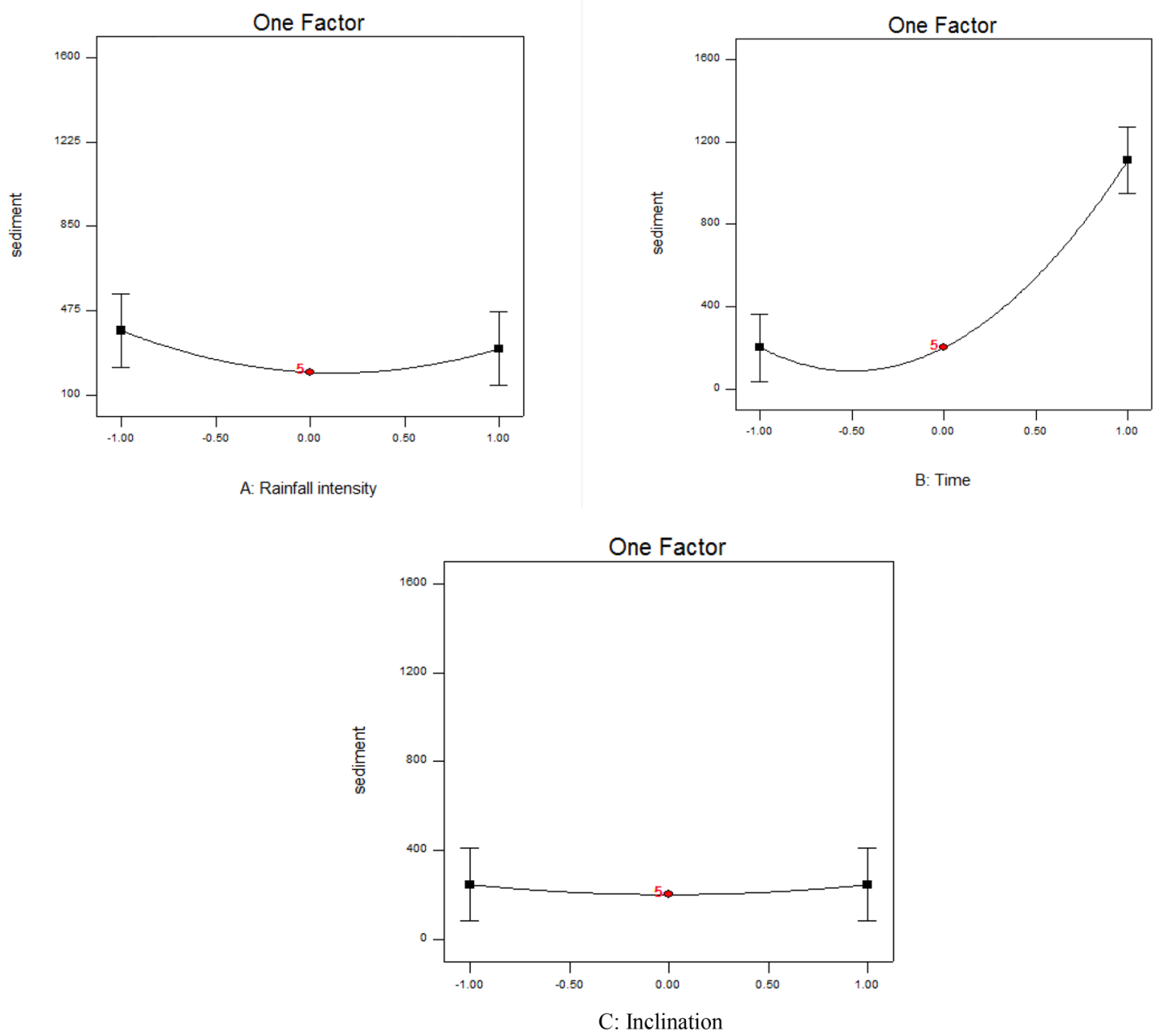

Figure 5. Results of single-factor analysis of the effect of changes in (A) rainfall intensity $(30,60$, and $90 \mathrm{~mm} / \mathrm{h}),($ B $)$ rainfall duration $(3,5$, and $7 \mathrm{~min})$, and $(\mathbf{C})$ slope $(5,15$, and $25 \%)$ on the amount of sediment $(\mathrm{g} /$ $\mathrm{m}^{2} / \mathrm{h}$ ) lost from the test beds.

of raindrops from less than $0.25 \mathrm{~mm}$ to more than $0.25 \mathrm{~mm}$, sediment production has previously been found to increase to $89.7 \%{ }^{60}$. The single-factor analysis also showed that soil loss remained almost constant with increasing slope (Fig. 5). The reason for this could be related to the nature of soil particles, e.g., it is possible that the intensities applied were able to transfer particles of a certain size, and slope changes had little effect on the amount transported ${ }^{61,62}$.

Interactive effects of multiple factors on soil loss. Three-dimensional diagrams showing the simultaneous effects of the different factors on the amount of sediment produced in the simulated rainfall events revealed that as the duration and intensity of precipitation increased, the amount of sediment also increased (Fig. 6). Rainfall duration had a stronger effect than rainfall intensity, but the effect of both factors was exponential and the amount of sediment increased sharply with increasing test duration (Fig. 6A).

Comparison of the combined and effect of rainfall intensity and inclination on soil loss activation showed that the effect of rainfall intensity was stronger. Higher-intensity rainfall is likely to separate more soil particles and move them more rapidly. Increasing the inclination of the plot surface further increased the production of sediment (Fig. 6B). Comparison of the combined effect of rainfall duration and inclination showed that both these actors were effective in increasing runoff. Again, rainfall duration had a stronger effect, and the increase in sediment over time was exponential (Fig. 6C). The changes in sediment production indicate the complexity of the erosion cycle, which cannot be examined in one dimension. These changes reflect the combined effects of the intensity and duration of precipitation and differences in soil characteristics ${ }^{42}$. Erosion and sediment changes are very complex in the early stages, but over time the process of runoff and sediment alters to constant change (ascending or descending) ${ }^{63}$. The level of change is determined by the soil texture ${ }^{64-66}$, the initial soil moisture ${ }^{37,67}$, and the intensity of precipitation ${ }^{36,66}$. Studying these in an integrated manner was a novel aspect of the present study.

The results of this study showed that sediment loss increased in the first stage of precipitation and with increased rainfall intensity, but decreased over time as the availability of transportable particles declined. However, higher-rainfall intensity increases the capacity of runoff to transport sediment, allowing it to carry other, 


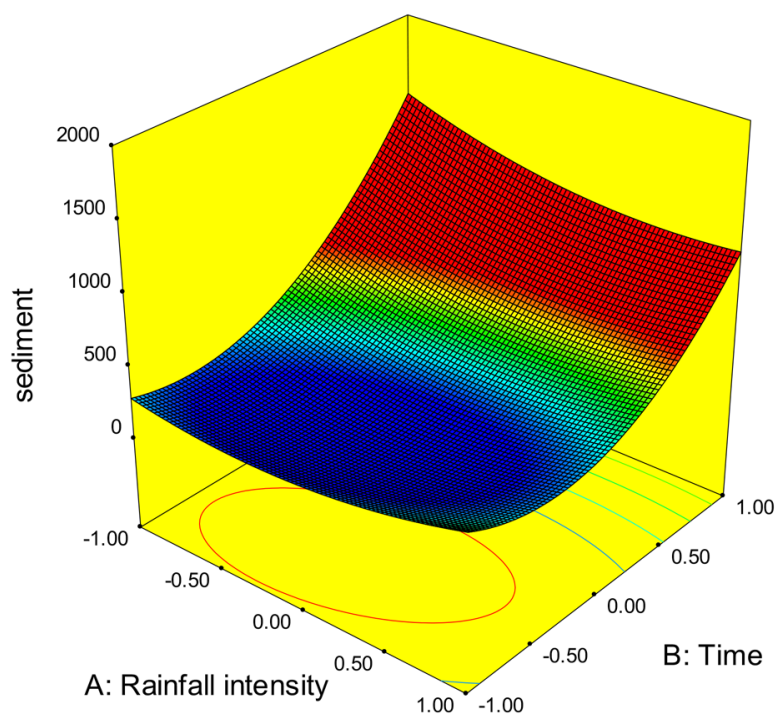

A

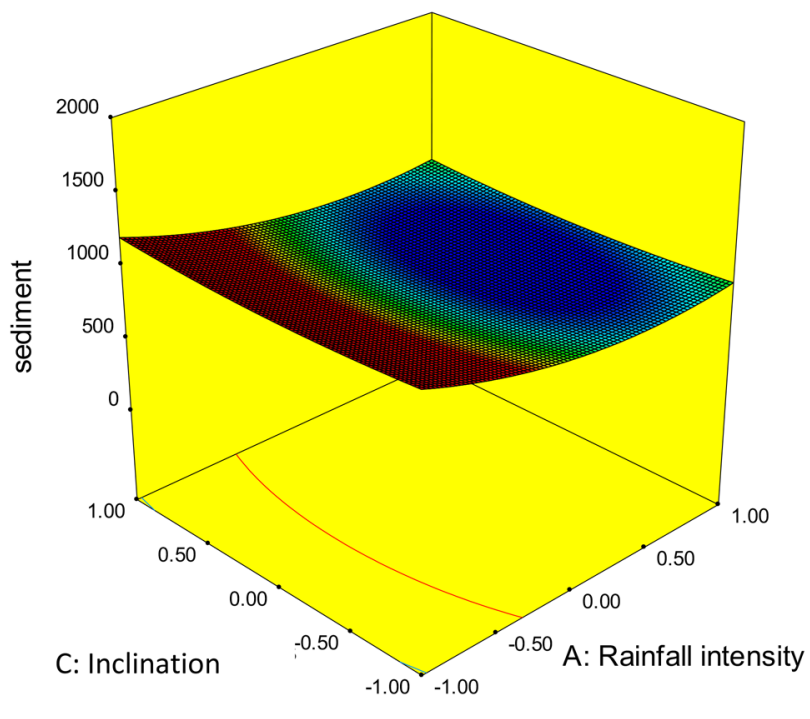

B

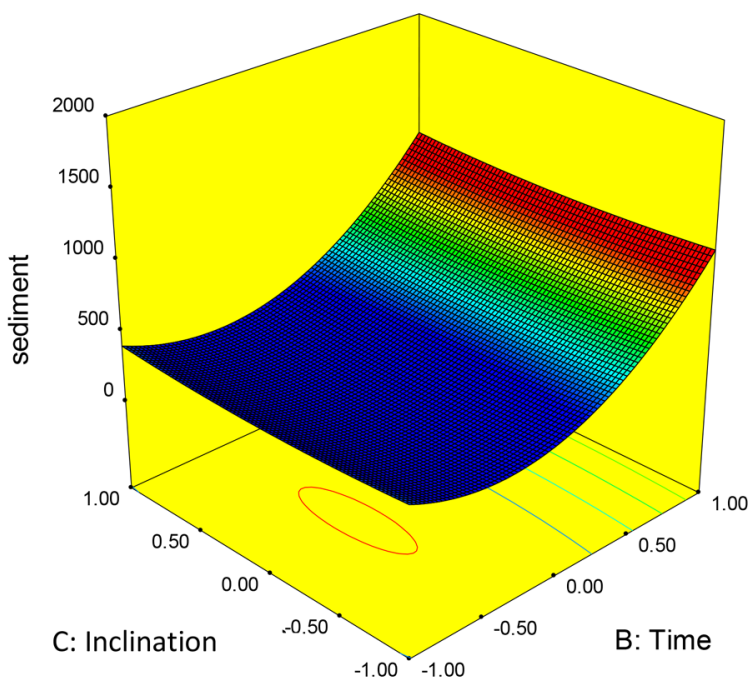

$\mathrm{C}$

Figure 6. Comparison of the combined effect of (A) rainfall intensity and rainfall duration, (B) rainfall intensity and slope, and $(\mathbf{C})$ rainfall duration and slope on sediment loss $\left(\mathrm{g} / \mathrm{m}^{2} / \mathrm{h}\right)$ from the test beds.

larger soil particles, as reported in other study areas under field conditions ${ }^{68-70}$. Our results showed that inclination change also affected the amount of sediment production, confirming previous findings ${ }^{71,72}$.

\section{Conclusions}

The effects of three levels of three factors (rainfall intensity, rainfall duration, and inclination) were examined under laboratory conditions with simulated rainfall experiments. The results showed that production of soil loss and runoff, and the course of the erosion process, were altered when several factors were applied simultaneously. Single-factor analysis showed that rainfall intensity was more effective than other factors in runoff production, but that rainfall duration played a more important role in sediment production. Multi-factor analysis showed that the combined effect of rainfall intensity and slope increased runoff production by about twice the level caused by the single most important factor (i.e., rainfall intensity). Moreover, the combined effect of rainfall intensity and duration increased soil loss production by about $24 \%$ compared with the most important single-factor (i.e., rainfall duration). The results also showed that in the initial stages of erosion, when there is more transportable sediment available at plot level (soil particles), the amount of runoff was lower and the rate of erosion was higher. In the final stages of erosion, the amount of soil loss decreased due to lack of erosive particles, but a larger volume of runoff was produced from the saturated soil. A quadratic model was found to be the best model for predicting the effects of rain intensity, rainfall duration, and slope on runoff $($ F-value $=12.86)$ and sediment $($ F-value $=12.90)$. The $\mathrm{R}^{2}$ and Adj- $\mathrm{R}^{2}$ values were high in both cases ( 0.94 and 0.86 , respectively), indicating high accuracy of model 
prediction based on experimental data. Water erosion removes considerable volumes of soil in different regions worldwide. This study provides a more accurate method for assessment of the water erosion process at laboratory and larger scale. The results can be used to formulate appropriate national and international measures to control erosion. They can also be used in designing water structures, and in assessing soil sensitivity to erosion and the effect of different factors on water erosion.

Received: 12 September 2020; Accepted: 3 November 2020

Published online: 19 November 2020

\section{References}

1. Assembly, G. Sustainable development goals. Transform World SDGs 2030, 338-350 (2015).

2. Griggs, D. et al. Policy: Sustainable development goals for people and planet. Nature 495(7441), 305 (2013).

3. Whitbread, A. et al. Strategies and policies to reach a land-degradation neutral world. 39-45 (2017).

4. Lv, C. et al. Erosion characteristics of different reclaimed substrates on iron tailings slopes under simulated rainfall. Sci. Rep. 10(1), $1-12(2020)$.

5. Kroese, J. S. et al. Agricultural land is the main source of stream sediments after conversion of an African montane forest. Sci. Rep. 10(1), 1-15 (2020).

6. Han, Z., Zhong, S., Ni, J., Shi, Z. \& Wei, C. Estimation of soil erosion to define the slope length of newly reconstructed gentle-slope lands in hilly mountainous regions. Sci. Rep. 9(1), 1-11 (2019).

7. Shojaei, S., Ardakani, M. A. H. \& Sodaiezadeh, H. Simultaneous optimization of parameters influencing organic mulch test using response surface methodology. Sci. Rep. 10(1), 1-11 (2020).

8. Lucatello, S., \& Huber-Sannwald, E. Sustainable development goals and drylands: Addressing the interconnection. In Stewardship of Future Drylands and Climate Change in the Global South, 27-40. Springer, Cham; https://doi.org/10.1007/978-3-030-22464-6_2 (2020).

9. Kamau, S., Barrios, E., Karanja, N. K., Ayuke, F. O. \& Lehmann, J. Dominant tree species and earthworms affect soil aggregation and carbon content along a soil degradation gradient in an agricultural landscape. Geoderma 359, 113983 (2020).

10. Jahanbakhshi, F., Ekhtesasi, M. R., Talebi, A. \& Piri, M. Investigation of Sediment production and runoff generation on rock formations of Shirkooh slopes of Yazd by using a rainfall simulator. JWSS-Isfahan Univ. Technol. 22(2), 287-299 (2018).

11. Rodrigo-Comino, J., Keesstra, S. \& Cerdà, A. Soil erosion as an environmental concern in Vineyards: The case study of celler del roure, Eastern Spain, by means of rainfall simulation experiments. Beverages 4(2), 31. https://doi.org/10.3390/beverages4020031 (2018).

12. Brevik, E. C. et al. Soil and human health: Current status and future needs. Air Soil Water Res. 13, 11. https://doi.org/10.1177/11786 $22120934441(2020)$

13. Karlen, D. L. et al. Soil quality: A concept, definition, and framework for evaluation (A Guest Editorial). Soil Sci. Soc. Am. J. 61, 4-10. https://doi.org/10.2136/sssaj1997.03615995006100010001x (1997).

14. Nobile, C. M., Bravin, M. N., Becquer, T. \& Paillat, J. M. Phosphorus sorption and availability in an andosol after a decade of organic or mineral fertilizer applications: Importance of $\mathrm{pH}$ and organic carbon modifications in soil as compared to phosphorus accumulation. Chemosphere 239, 124709 (2020).

15. Bayat, F. et al. Analyzing long-term soil erosion in a ridge-shaped persimmon plantation in eastern Spain by means of ISUM measurements. CATENA 183, 104176. https://doi.org/10.1016/j.catena.2019.104176 (2019).

16. Borrelli, P. et al. Towards a Pan-European assessment of land susceptibility to wind erosion. Land Degrad. Dev. 27, $1093-1105$. https://doi.org/10.1002/ldr.2318 (2016).

17. Evans, R. The erosional impacts of grazing animals. Prog. Phys. Geogr. 22, 251-268. https://doi.org/10.1177/030913339802200206 (1998).

18. Gholami, H., Telfer, M. W., Blake, W. H. \& Fathabadi, A. Aeolian sediment fingerprinting using a Bayesian mixing model. Earth Surf. Process Landf. 42, 2365-2376. https://doi.org/10.1002/esp.4189 (2017).

19. Mirzaee, S. et al. Effects of hydrological events on morphological evolution of a fluvial system. J. Hydrol. 563, 33-42. https://doi. org/10.1016/j.jhydrol.2018.05.065 (2018).

20. Aksoy, H. \& Kavvas, M. L. A review of hillslope and watershed scale erosion and sediment transport models. CATENA 64, 247-271 (2005).

21. Berger, C., Schulze, M., Rieke-Zapp, D. \& Schlunegger, F. Rill development and soil erosion: A laboratory study of slope and rainfall intensity. Earth Surf. Process Landf. 35(12), 1456-1467. https://doi.org/10.1002/esp.1989 (2010).

22. Zheng, M. et al. Simultaneous control of soil erosion and arsenic leaching at disturbed land using polyacrylamide modified magnetite nanoparticles. Sci. Total Environ. 702, 134997 (2020).

23. Gao, L., Bowker, M. A., Sun, H., Zhao, J. \& Zhao, Y. Linkages between biocrust development and water erosion and implications for erosion model implementation. Geoderma 357, 113973 (2020).

24. Novara, A. et al. Agricultural land abandonment in Mediterranean environment provides ecosystem services via soil carbon sequestration. Sci. Total Environ. 576, 420-429. https://doi.org/10.1016/j.scitotenv.2016.10.123 (2017).

25. Sannigrahi, S. et al. Responses of ecosystem services to natural and anthropogenic forcings: A spatial regression based assessment in the world's largest mangrove ecosystem. Sci. Total Environ. https://doi.org/10.1016/j.scitotenv.2020.137004 (2020).

26. Amiri, M., \& Pourghasemi, H. R. Mapping and preparing a susceptibility map of gully erosion using the MARS Model. In Gully Erosion Studies from India and Surrounding Regions, 405-413. Springer, Cham. (2020).

27. Koiter, A. J., Owens, P. N., Petticrew, E. L. \& Lobb, D. A. The role of soil surface properties on the particle size and carbon selectivity of interrill erosion in agricultural landscapes. CATENA 153, 194-206. https://doi.org/10.1016/j.catena.2017.01.024 (2017).

28. Pardini, G., Gispert, M., Emran, M. \& Doni, S. Rainfall/runoff/erosion relationships and soil properties survey in abandoned shallow soils of NE Spain. J. Soils Sedim. 17, 499-514. https://doi.org/10.1007/s11368-016-1532-0 (2017).

29. Bugna, G. C., Grace, J. M. \& Hsieh, Y. P. Sensitivity of using stable water isotopic tracers to study the hydrology of isolated wetlands in North Florida. J. Hydrol. 580, 124321 (2020).

30. Liu, T. et al. Paleoflood hydrology on the lower Green River, upper Colorado River Basin, USA: An example of a naturalist approach to flood-risk analysis. J Hydrol. 580, 124337 (2020).

31. Pumo, D., Arnone, E., Francipane, A., Caracciolo, D. \& Noto, L. V. Potential implications of climate change and urbanization on watershed hydrology. J. Hydrol. 554, 80-99 (2017).

32. Lavrnić, S. et al. Hydrological and hydraulic behaviour of a surface flow constructed wetland treating agricultural drainage water in northern Italy. Sci. Total Environ. 702, 134795 (2020).

33. Kavian, A., Mohammadi, M., Cerda, A., Fallah, M. \& Abdollahi, Z. Simulated raindrop's characteristic measurements. A new approach of image processing tested under laboratory rainfall simulation. CATENA 167, 190-197. https://doi.org/10.1016/j.caten a.2018.04.034 (2018). 
34. Kavian, A., Mohammadi, M., Cerdà, A., Fallah, M. \& Gholami, L. Design, manufacture and calibration of the SARI portable rainfall simulator for field and laboratory experiments. Hydrol. Sci. J. 64(3), 350-360. https://doi.org/10.1080/02626667.2019.1581364 (2019).

35. Ferro, V. \& Nicosia, A. Rill erosion processes on steep colluvial deposit slope under heavy rainfall in flume experiments with artificial rain by F. Jiang et al. CATENA 185, 103793 (2020).

36. Wu, S., Chen, L., Wang, N., Li, J. \& Li, J. Two-dimensional rainfall-runoff and soil erosion model on an irregularly Rilled Hillslope. J. Hydrol. 580, 124346 (2020).

37. Xu, S., Liu, Y., Gong, J., Wang, C. \& Wang, Z. Comparing differences among three ecosystem service proxies for soil erosion prevention and their combination characteristics at local scales. Ecol. Indic. 110, 105929 (2020).

38. Nambajimana, J. D. D. et al. Land use change impacts on water erosion in Rwanda. Sustainability 12(1), 50 (2020).

39. Kiani, H. M., Sadeghi, S. H. \& Asadi, H. Inter-storm variability of coefficient of variation of runoff volume and soil loss during rainfall and erosion simulation replicates. Iran. J. Ecohydrol. 4(1), 191-199 (2017).

40. Balacco, G. The interrill erosion for a sandy loam soil. J. Sedim. Res. 28(3), 329-337 (2013).

41. Fu, S., Liu, B., Liu, H. \& Xu, L. The effect of slope on interrill erosion at short slopes. CATENA 84(1-2), 29-34 (2011).

42. Armstrong, A., Quinton, J. N., Heng, B. C. P. \& Chandler, J. H. Variability of interrill erosion at low slopes. Earth Surf. Process Landf. 36(1), 97-106 (2011).

43. Defersha, M. B. \& Melesse, A. Effect of RI, slope and antecedent moisture content on sediment concentration and sediment enrichment ratio. CATENA 90, 47-52 (2012).

44. Zhao, Q. et al. Effects of RI and slope gradient on erosion characteristics of the red soil slope. Stoch. Env. Res. Risk A. 29(2), 609-621 (2015).

45. Mahmoodabadi, M. \& Sajjadi, S. A. Effects of rain intensity, slope gradient and particle size distribution on the relative contributions of splash and wash loads to rain-induced erosion. Geomorphology 253, 159-167 (2016).

46. Donjadee, S. \& Tingsanchali, T. Soil and water conservation on steep slopes by mulching using rice straw and vetiver grass clippings. Agric. Nat. Resour. 50(1), 75-79 (2016).

47. Sadeghi, S. H. R., Kiani Harchegani, M. \& Asadi, H. Variability of particle size distributions of upward/downward splashed materials in different rainfall intensities and slope. Geoderma 290, 100-106 (2017).

48. Shojaei, S., Khammarnia, S., Shojaei, S. \& Sasani, M. Removal of reactive red 198 by nanoparticle zero valent iron in the presence of hydrogen peroxide. J. Water Environ. Nanotechnol. 2(2), 129-135 (2017).

49. Shojaei, S., Shojaei, S. \& Pirkamali, M. Application of Box-Behnken design approach for removal of acid black 26 from aqueous solution using zeolite: Modeling, optimization, and study of interactive variables. Water Conservation Science and Engineering 4(1), 13-19 (2019)

50. Shojaei, S., Ardakani, M. A. H. \& Sodaiezadeh, H. Optimization of parameters affecting organic mulch test to control erosion. J. Environ. Manag. 249, 109414 (2019).

51. Pourabadeh, A. et al. Experimental design and modelling of removal of dyes using nano-zero-valent iron: A simultaneous model. Int. J. Environ. Anal. Chem. https://doi.org/10.1080/03067319.2019.1657855 (2019).

52. Shojaei, S. Optimization of process variables by the application of response surface methodology for dye removal using nanoscale zero-valent iron. Int. J. Environ. Sci. Technol. 16(8), 4601-4610 (2019).

53. Shen, H. O. et al. Rainfall and inflow effects on soil erosion for hillslopes dominated by sheet erosion or rill erosion in the Chinese Mollisol region. J. Mt. Sci. 15(10), 2182-2191 (2018).

54. Vancampenhout, K., Wondim, G. T., Deckers, J., Poesen, J., Haile, M., \& Nyssen, J. Sheet and Rill erosion and its control: Lessons from Dogu’a Tembien. In Geo-trekking in Ethiopia’s Tropical Mountains, 319-331. Springer, Cham. (2019).

55. Novara, A., Stallone, G., Cerdà, A. \& Gristina, L. The effect of shallow tillage on soil erosion in a semi-arid vineyard. Agronomy 9(5), 257 (2019).

56. Lal, R. Soil erosion by wind and water: Problems and prospects. Soil Eros. Res. Methods 2, 1-9 (1994).

57. Menendez, H. M. et al. A spatial landscape scale approach for estimating erosion, water quantity, and quality in response to South Dakota grassland conversion. Nat. Resour. Model. 33(1), e12243 (2019).

58. Lu, J., Zheng, F., Li, G., Bian, F. \& An, J. The effects of raindrop impact and runoff detachment on hillslope soil erosion and soil aggregate loss in the Mollisol region of Northeast China. Soil Tillage Res. 161, 79-85. https://doi.org/10.1016/j.still.2016.04.002 (2016).

59. Vaezi, A. R., Ahmadi, M. \& Cerdà, A. Contribution of raindrop impact to the change of soil physical properties and water erosion under semi-arid rainfalls. Sci. Total Environ. 583, 382-392. https://doi.org/10.1016/j.scitotenv.2017.01.078 (2017).

60. Hairsine, P. B. \& Rose, C. W. Modeling water erosion due to overland flow using physical principles, I Sheet flow. Water Resour. Res. 28(1), 237-243 (1992).

61. Martínez-Mena, M. et al. Long-term effectiveness of sustainable land management practices to control runoff, soil erosion, and nutrient loss and the role of rainfall intensity in Mediterranean rainfed agroecosystems. CATENA 187, 104352 (2019).

62. Cerdà, A. \& Rodrigo-Comino, J. Is the hillslope position relevant for runoff and soil loss activation under high rainfall conditions in vineyards?. Ecohydrol. Hydrobiol. 20(1), 59-72 (2020).

63. Hu, Y., Fister, W. \& Kuhn, N. J. Inherent interreplicatevariability during small-scale rainfall simulations. J. Soil Sed. 16(6), 1809-1814 (2016).

64. Meshram, D., Gorantiwar, S. D., Wadne, S. S., \& Kumar, K. A. Planning, Designing and construction of series of check dams for soil and water conservation in a micro-watershed of Gujarat, India. In Gully Erosion Studies from India and Surrounding Regions (pp. 337-343). Springer, Cham. (2020).

65. Zaimes, G. N., Tardio, G., Iakovoglou, V., Gimenez, M., Garcia-Rodriguez, J. L., \& Sangalli, P. New tools and approaches for soil and water bioengineering in the mediterranean to enhance water quality. In Frontiers in Water-Energy-Nexus-Nature-Based Solutions, Advanced Technologies and Best Practices for Environmental Sustainability (pp. 485-487). Springer, Cham. (2020).

66. Ge, J., Wang, S., Fan, J., Gongadze, K. \& Wu, L. Soil nutrients of different land-use types and topographic positions in the waterwind erosion crisscross region of China's Loess Plateau. CATENA 184, 104243 (2020).

67. Fenta, A. A. et al. Land susceptibility to water and wind erosion risks in the East Africa region. Sci. Total Environ. 703, 135016 (2020).

68. Cerdà, A. \& Rodrigo-Comino, J. Is the hillslope position relevant for runoff and soil loss activation under high rainfall conditions in vineyards?. Ecohydrol. Hydrobiol. 20, 59-72. https://doi.org/10.1016/j.ecohyd.2019.05.006 (2020).

69. Rodrigo-Comino, J., Senciales, J. M., Cerdà, A. \& Brevik, E. C. The multidisciplinary origin of soil geography: A review. Earth Sci. Rev. 177, 114-123. https://doi.org/10.1016/j.earscirev.2017.11.008 (2018).

70. Rodrigo-Comino, J. et al. High variability of soil erosion and hydrological processes in Mediterranean hillslope vineyards (Montes de Málaga, Spain). CATENA 145, 274-284. https://doi.org/10.1016/j.catena.2016.06.012 (2016).

71. Vaezi, A. R. \& Ebadi, M. Particle size distribution of surface-eroded soil in different rainfall intensities and slope gradients. J. Water Soil 31(1), 216-229 (2017)

72. Bogunovic, I., Telak, L. J. \& Pereira, P. Experimental comparison of runoff generation and initial soil erosion between vineyards and croplands of Eastern Croatia: A case study. Air Soil Water Res. 13, 10. https://doi.org/10.1177/1178622120928323 (2020). 


\section{Author contributions}

S.S. conceived the original idea. J.R. and Z.K. helped supervise the project. S.S. performed the analytical calculations and the numerical simulations. S.S. and J.R. and Z.K. wrote the manuscript. All the authors participated in the development of the study and the experiments.

\section{Funding}

Open Access funding enabled and organized by Projekt DEAL.

\section{Competing interests}

The authors declare no competing interests.

\section{Additional information}

Correspondence and requests for materials should be addressed to S.S. or J.R.-C.

Reprints and permissions information is available at www.nature.com/reprints.

Publisher's note Springer Nature remains neutral with regard to jurisdictional claims in published maps and institutional affiliations.

(c) (i) Open Access This article is licensed under a Creative Commons Attribution 4.0 International License, which permits use, sharing, adaptation, distribution and reproduction in any medium or format, as long as you give appropriate credit to the original author(s) and the source, provide a link to the Creative Commons licence, and indicate if changes were made. The images or other third party material in this article are included in the article's Creative Commons licence, unless indicated otherwise in a credit line to the material. If material is not included in the article's Creative Commons licence and your intended use is not permitted by statutory regulation or exceeds the permitted use, you will need to obtain permission directly from the copyright holder. To view a copy of this licence, visit http://creativecommons.org/licenses/by/4.0/.

(C) The Author(s) 2020 